\title{
Space technology based rainfall water flooding, solutions and preventive measures
}

\author{
Gar Al-nabi Ibrahim Mohamed ${ }^{1^{*}}$ and Faisal Althobiani ${ }^{2}$ \\ ${ }^{1}$ Hydrographic Surveying Department, ${ }^{2}$ Department of Marine Engineering Faculty of Maritime Studies, King Abdulaziz University, KSA \\ Received 01 Oct 2017, Accepted 03 Dec 2017, Available online 13 Dec 2017, Vol.5 (Nov/Dec 2017 issue)
}

\begin{abstract}
This paper investigated the causes of surface rainfall floods, using a case study in the Sudan. The effort made in the investigation revealed the role that can be played by the open data sources in pointing out the real causes of these floods, using the topographical and hydrological models of the study area. The study area is directly affected by a water volume of 2,021,800 $\mathrm{m}^{3}$, but the indirect effect caused by the man-made features blocking the natural course of the rainfall water is more than hundred times the direct effect $\left(269,798,800 \mathrm{~m}^{3}\right)$. In fact, the indirect flooding is 133.445 times the direct one $(269,798,800 / 2,021,800)$. Accordingly, open data sources can be adopted to form the topographical and hydrological models of the area and solutions can made for existing floods problems and preventive measures can be made for new urban planning areas.
\end{abstract}

Keywords: Flooding, open data source, floods causes, urban planning, catchment area, irrigation canal, highway.

\section{Introduction}

Though water is very important for humans, animals and plants, but can be hazardous and source of crises if not properly considered. Surface rainfall water flooding is the major source of human crises worldwide. Almost most of the world areas are affected by these floods every year. To name, but a few, in the year 2007 the flash flooding affected three main states in the Sudan and resulted in 150,000 damaged homes and 750,000 homeless [10]. Table 1 , below gives a summary of the damage caused by the Sudan rainfall floods in the years 2007, 2013 and 2016.

Table $1 \mathrm{~A}$ summary the floods damages in the Sudan in 2007, 2013 and 2016

\begin{tabular}{|c|c|c|c|c|c|}
\hline Year & $\begin{array}{c}\text { No. of } \\
\text { affected } \\
\text { states }\end{array}$ & $\begin{array}{c}\text { No. of } \\
\text { deaths }\end{array}$ & $\begin{array}{c}\text { No. of } \\
\text { damaged } \\
\text { houses }\end{array}$ & $\begin{array}{c}\text { No. of } \\
\text { homeless }\end{array}$ & $\begin{array}{c}\text { No. of } \\
\text { injured }\end{array}$ \\
\hline 2007 & 3 & 64 & 150,000 & 750,000 & 335 \\
\hline 2013 & $13-16$ & 50 & 25,000 & 300,000 & --- \\
\hline 2016 & 2 & 9 & 541 & 15,000 & --- \\
\hline
\end{tabular}

The 2016 floods in Saudia Arabia forced the authorities to close the schools in and around Riyad, roads were flooded with water and cars were submerged [9]. In the year 2017, Saudia Arabia was affected by floods in Asir region (April) and Mecca region (November), one dead person, 10 injured persons and 280 rescued from submerged cars were reported [12].

*Corresponding author's ORCID ID: 0000-0003-4655-6736 DOI: http://Dx.Doi.Org/10.14741/ljmcr/5.6.32
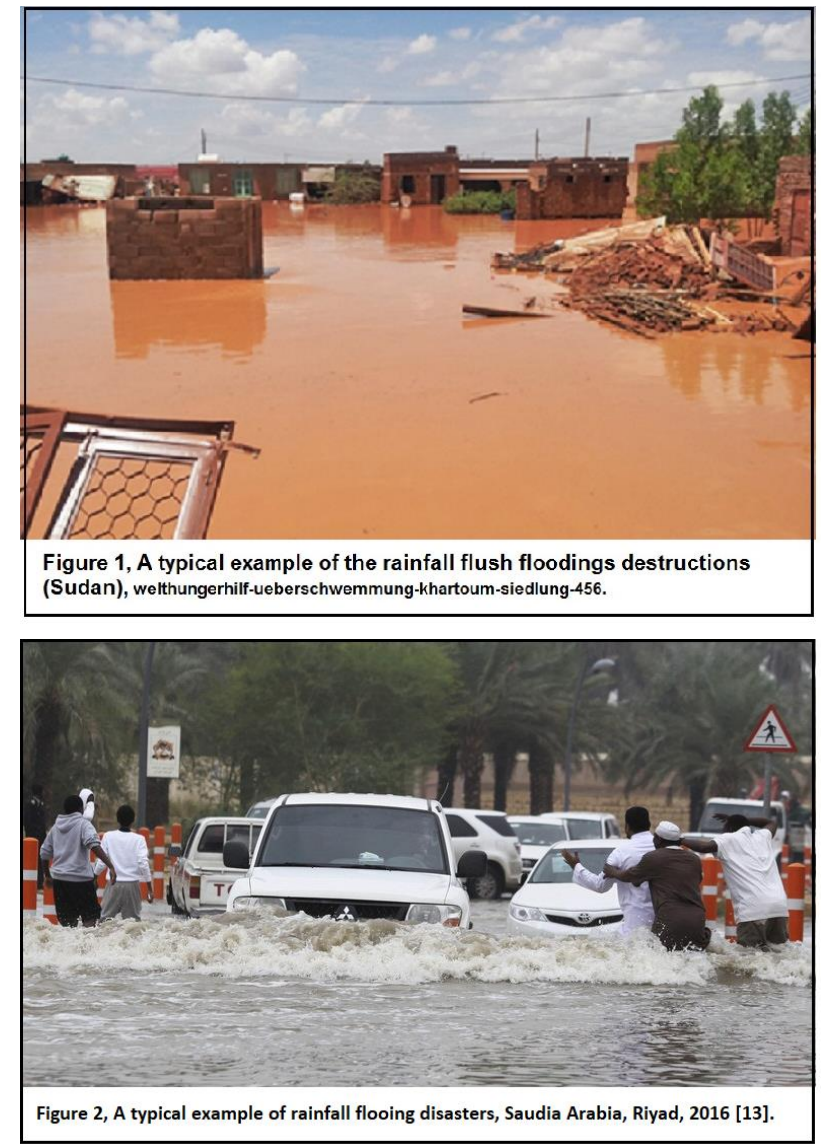

In August, 2017 India, Nepal and Bangladish were devastated by two weeks of heavy mansoon rains flooding, where 41 million people were affected and 1000 people were reported dead [11]. 
This clearly revealed that rainfall floods are a major source of crises worldwide. The effort made in this research was directed towards, the role that the space technology and open data sources can play in the rainfall disasters solutions and preventive measures. Figures 1 and 2 show typical examples of the rain floods disasters

\section{The study area}

The research study area is located in the east Nile locality, Khartoum state, Sudan. It is a semi urban area located along the eastern side of the Blue Nile river, where residency and agriculture are running in parallel. The exact floods affected area is called Marabeea-Alshareef. This area was affected by rainfall floods in a number of years but the most worse floods hit the area in the year 2013. It is bounded by an agricultural zone in the north side, a large irrigation canal in the west and north sides and a highway in the west side. Figure 3, shows the general location of the study area and its main features.

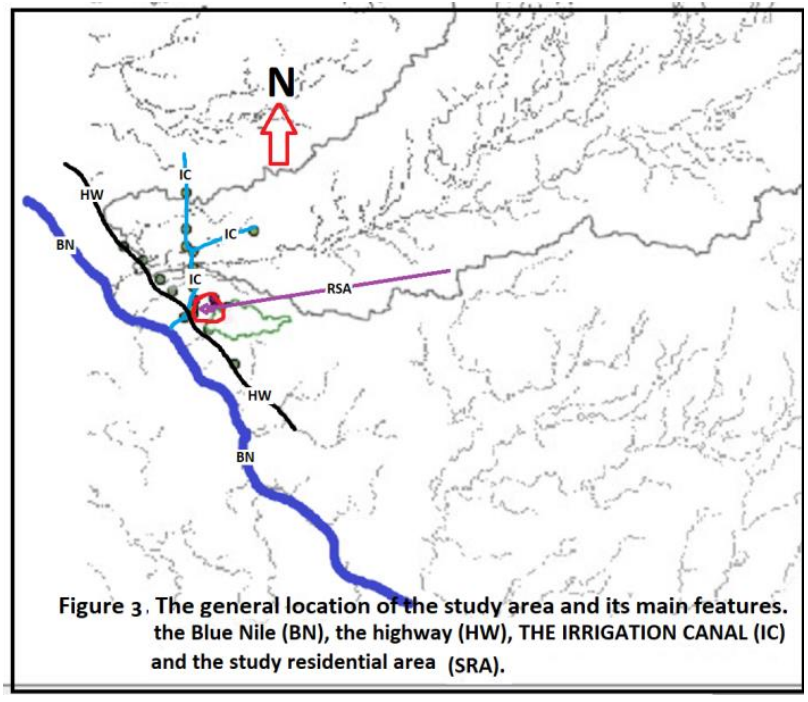

1) The research objectives

The objectives of this research may be summarized by the following:

a) To study the floods affected area and investigate the main causes of these floods in the area.

b) To suggest solutions for the existing floods causes and future preventive measures for urban planning areas.

2) Research methodology

The research methodology used in this investigation was as follows:

a) The topographic characteristics and the main features in the study area were located using Google Earth satellite images and the on-line GIS facilities.

b) The STRM90 digital elevation model of the area was downloaded and processed to create the hydrological model for the area and derive the draining areas (catchment areas) affecting the study area using QGIS application program.

c) The interaction between the rainfall draining waters and the features in the study area was investigated to point out the main causes of the floods in the study area.

\section{Results and discussions}

Figure 4 shows the main rainfall catchment areas affecting the study area. It revealed that the study area is affected by two catchment areas (CA1 and CA2), table1. CA1 is directly affecting the study area and in fact some of the study area falls inside it. Although CA2 is not affecting the study area directly but it is very clear that the rainfall water is blocked by the man-made features in the area, the irrigation canal and the highway. This forces the rainfall water to accumulate in large volumes and back up in low lands in the vicinity and as it can be seen our study area is a no exception from these vicinity areas. Table 2 , shows the catchment areas data, where the volume of water was calculated using the minimum rate of rainfall in the study area $(200 \mathrm{~mm})$.

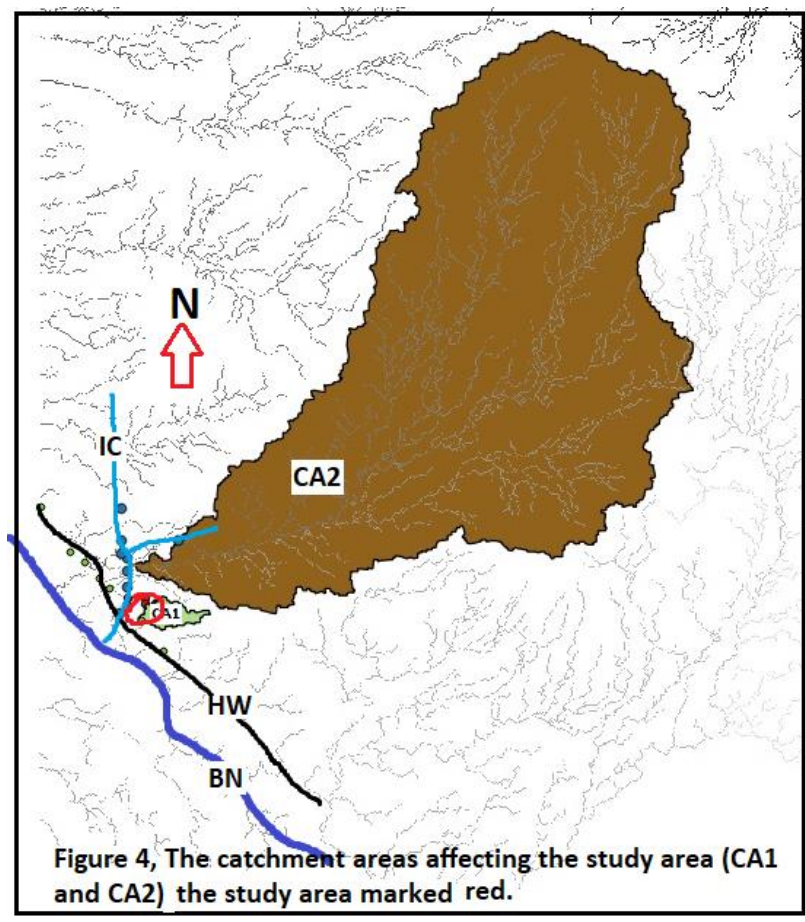

Table 2 Catchment areas data

\begin{tabular}{|c|c|c|c|}
\hline $\begin{array}{c}\text { Catchment } \\
\text { area }\end{array}$ & Area $(\mathrm{km} 2)$ & $\begin{array}{c}\text { Perimeter } \\
(\mathrm{km})\end{array}$ & Volume $(\mathrm{m} 3)$ \\
\hline CA1 & 10.109 & 23.733 & $2,021,800$ \\
\hline Ca2 & 1348.994 & 282.808 & $269,798,800$ \\
\hline
\end{tabular}

Table2 revealed that the direct drainage volume from CA1 is quite reasonable and manageable $\left(2,021,800 \mathrm{~m}^{3}\right)$, but the study area main problem is the indirect drainage volume from CA2 $\left(269,798,800 \mathrm{~m}^{3}\right)$, which is mainly due 
to the blockage of the rainfall water by the irrigation canal and the highway. This was clearly demonstrated by the August 2013 floods that hit the residential area, where the water level reached the second-floor level in the multi-story buildings in the area. These results demonstrated that the study residential area (Marabeea Alshareef) would continue to suffer from the rainfall floods whenever, the rainfall rate exceeds the average and the only solution is to drain the water coming from CA2 into the Blue Nile via proper drainage elements along the irrigation canal and the high way.

\section{Conclusions}

The study area is directly affected by $269,798,800 \mathrm{~m}^{3}$ of rainfall water but the damaging effect is coming from the indirect effect caused by the man-made features in the area $\left(269,798,800 \mathrm{~m}^{3}\right)$. This demonstrated the real need for proper data integration in urban planning. The effort made in the paper revealed that the open data sources can play this role. Floods effected areas and new urban planning areas can be studied and solutions for existing problems and preventive measures for future planning areas can be made.

It should be mentioned that non-government organizations (NGOs) are making an appreciated effort related to rainfall floods disasters worldwide, however, it is high time to devote some of this effort to encourage government authorities to use the free of charge open data sources in urban planning to avoid a lot of rainfall floods in their areas by taking the necessary floods preventive measures.

\section{References}

[1]. Sudan floods situation report No. 2 (pdf). World Health Organization. 19 August 2013. Retrieved 24 August 2013.

[2]. Sudan: Flash Update August 22, 2013 (issue \# 6). reliefweb.int. UN Office for the Coordination of Humanitarian Affairs. 22 August 2013. Retrieved 24 August 2013.

[3]. WHO puts number of Sudan flood victims at 320,000 . Sudan Tribune. 21 August 2013. Retrieved 24 August 2013.

[4]. Tran, Mark (23 August 2013). Sudan's worst floods for 25 years leave 500,000 facing destruction and disease. The Guardian. Retrieved 24 August 2013.

[5]. Sudan floods situation report No. 1 (pdf). World Health Organization. 14 August 2013. Retrieved 24 August 2013.

[6]. Sudanese lawmaker accuses government of negligence in wake of deadly floods. Sudan Tribune. 5 August 2013. Retrieved 24 August 2013.

[7]. Migiro, Kathy (7 August 2013). Sudan government under fire as flash floods kill 11, displace 100,000. trust.org. Thomson Reuters Foundation. Retrieved 24 August 2013.

[8]. https://www.theguardian.com/globaldevelopment/2013/aug/23/sudan-floods-worst-25-years

[9]. http://floodlist.com/africa/sudan-floods-70-dead-julyaugust-2016.

[10].http://www.unspider.org/sites/default/files/28_AmnaAhmedHamid_NCR. pdf.

[11].https://en.wikipedia.org/wiki/2007_Sudan_floods.

[12].http://reliefweb.int/map/sudan/flood-waters-overkhartoum-state-sudan-8-august-2014.

[13]. https://www.youtube.com/watch?v=1C9KX3vrH2Q 